\title{
Od Biblioteki Aleksandryjskiej do World Wide Web ${ }^{1}$
}

\begin{abstract}
Streszczenie. Celem artykułu jest wykazanie paraleli między WWW a Biblioteką Aleksandryjską. Koncepcyjnie WWW znajduje się pod wpływem wypracowanych w kulturze książki metod i sposobów organizacji i zarządzania informacją. Daje się bowiem wskazać podobieństwo między WWW a bibliotecznym zadaniem zabezpieczenia jak największej spuścizny piśmienniczego dziedzictwa kulturowego ludzkości, tj. zgromadzenia bogactwa informacyjnego in corpore i udostępnienia go in situ. Poza tym przyrost informacji w przestrzeni WWW (powstawanie coraz większej liczby stron WWW) doprowadził do konieczności stworzenia odpowiednich technologii informacyjnych, których zadaniem jest zarządzanie tymi cyfrowymi obiektami. Podczas tworzenia niektórych technologii nawiązano do głównej idei przyświecającej twórcom Biblioteki Aleksandryjskiej, tj. stworzenia pełnego repozytorium informacji. W artykule omówiono te technologie, wskazując konceptualne podobieństwo do Biblioteki Aleksandryjskiej.
\end{abstract}

SŁowA KLuczowe: Biblioteka Aleksandryjska, World Wide Web, kultura książki, repozytorium wiedzy i informacji.

\section{Biblioteka Aleksandryjska ${ }^{2}$}

Pierwsze próby zgromadzenia pełnego korpusu informacji związane są z powstaniem pisma fonetycznego oraz stworzeniem odpowiednich nośników informacji, które pozwoliły utrwalać wytwory

${ }^{1}$ Publikacja powstała w ramach grantu Wydziału Humanistycznego Uniwersytetu Marii Curie-Skłodowskiej nr BS-05-0000-D012 ZFIN00000040.

${ }^{2}$ Historię Biblioteki Aleksandryjskiej, jak również Nowej Biblioteki Aleksandryjskiej (Bibliotheca Alexandrina) szczegółowo przedstawiła Gabriela Meinardi. Por. G. Meinardi, Bibliotheca Alexandrina - "czwarta piramida" - świetność z gruzów, "Annales Academiae Paedagogicae Cracoviensis. Studia ad Bibliothecarum Scentiam Pertinentia" 2005, t. 25, nr 3, s. 3-10. 
pisma. Gromadzenie informacji związane jest więc z powstawaniem pierwszych bibliotek. Jedną z nich była założona w VII wieku p.n.e. Biblioteka Asurbanipala w Niniwie. Największą biblioteką świata starożytnego była jednak powstała w III wieku p.n.e. Biblioteka Aleksandryjska. Została ona założona przez Ptolemeusza I Sotera przy działającym w Aleksandrii Muzejonie (ówczesny naukowy instytut badawczy), który usytuowany był w pałacu królewskim ${ }^{3}$. O ile celem działania Biblioteki Asurbanipala było zgromadzenie całej wiedzy i dorobku kulturowego tamtego rejonu, o tyle celem Biblioteki Aleksandryjskiej było zebranie wszystkich książek (całego ówczesnego uniwersum książkowego) wytworzonych na całym świecie ${ }^{4}$. Zamierzenie to realizowano m.in. przez zabieranie wszystkim podróżującym przez Aleksandrię (głównie drogą morską) każdego manuskryptu, który był $\mathrm{w}$ ich posiadaniu. Zwracano im kopie tych $\mathrm{ksiacg}^{5}$. Inną praktyką było pożyczanie z zaprzyjaźnionych miast greckich kolejnych dzieł i ich kopiowanie. Wzorem poprzedniej metody i tu jedynie kopie wracały do poprzedniego właściciela, oryginały natomiast były włączane do aleksandryjskiej kolekcji bibliotecznej6. Taka praktyka doprowadziła do zgromadzenia ogromnej liczby woluminów. Zbiory Biblioteki Aleksandryjskiej za czasów rządów Juliusza Cezara zostały oszacowane na

${ }^{3}$ Por. D. Heller-Roazen, Tradition's destruction. On the library of Alexandria, "October Magazine" 2002, nr 100, s. 133-139.

${ }^{4}$ Król Asyrii - Asurbanipal - „zgromadził w swej nadwornej książnicy całość stworzonego przez ludy dorzecza Eufratu i Tygrysu piśmiennictwa, aby je uratować od zatracenia i aby je uczynić źródłem niewygasającej tradycji dla siebie i potomnych [...]. Gdyby rozumny, przewidujący władca nie był zgromadził rozproszonych po całym dorzeczu tabliczek z tekstami z zakresu historii, literatury pięknej, astronomii, medycyny, prawa i filologii, prawdopodobnie nigdy nie bylibyśmy poznali [...] wierzeń religijnych i osiągnięć naukowych babilońskich kapłanów [...]. Po raz drugi świat starożytny zabezpieczył w jednym miejscu całość dotychczasowego dorobku piśmienniczego na przełomie epoki helleńskiej i hellenistycznej [...]. Mianowicie z inicjatywy króla Egiptu Ptolemeusza I Sotera zespół wybitnych uczonych skupił w Aleksandrii [...] wszystko, co dotychczas umysł ludzki stworzył w zakresie poznania naukowego, myśli religijnej i filozoficznej, przeżycia estetycznego". K. Głombiowski, Teoria i metodologia nauki o ksiażce, Gdańsk 1985, s. 15-16. Ponadto istnieją dowody na to, że projekt działania Biblioteki Aleksandryjskiej zakładał również translację tekstów barbarzyńskich (niegreckich) na grekę, tak aby wypełnić główne zadanie, czyli zgromadzić pełne dziedzictwo kulturowe ówczesnego świata. Por. D. Heller-Roazen, op.cit., s. 142.

5 Por. M. Arseneault, Alexandria, from papyrus to the Internet, "The Unesco Courier" 1999, t. 52, nr 4, s. 41.

${ }^{6}$ Por. D. Heller-Roazen, op.cit., s. 141. 
około 700 tysięcy zwojów ${ }^{7}$. Duża wartość biblioteki wynikała nie tylko z ogromnej, jak na tamte czasy, liczby posiadanych tomów, ale też $z$ różnorodności dziedzin wiedzy, których one dotyczyły ${ }^{8}$. Plan działania biblioteki nie koncentrował się tylko na zebraniu wszystkich dzieł ówczesnego świata, lecz również na próbie zachowania ich dla kolejnych pokoleń. Dbając o zabezpieczenie zbiorów przed zniszczeniem, głównie z powodu krótkiej żywotności papirusu, bibliotekarze co 150 lat obowiązkowo przepisywali wszystkie zgromadzone dokumenty ${ }^{9}$.

Można uznać, iż Biblioteka Aleksandryjska stała się symbolem utopijnej idei zgromadzenia pełnej kolekcji piśmiennictwa. Zdzisław Dobrowolski zwrócił uwagę na fakt, że do tej idei w eseju Biblioteki przyszłości nawiązał Joseph Licklider ${ }^{10}$. Pisał on bowiem, iż w niedalekiej przyszłości będzie możliwe umieszczenie w pamięci komputerów całego uniwersum książek ${ }^{11}$. Pomysły Licklidera, a tym samym również ta dawna idea, odżyły wraz z narodzinami nowoczesnych technologii informacyjnych i rozwojem sieci internetowej.

\section{Projekt Gutenberg}

Zdaje się, że to przyczyny merkantylne wpłynęły na rozpoczęcie procesu digitalizowania dokumentów. Pojawiające się nośniki cyfrowe stały się bowiem zagrożeniem dla tych firm, których praca opierała się głównie na nośnikach papierowych. Na przełomie lat 60. i 70., jak pisze Piotr Gawrysiak,

rezygnacja z papieru jako głównego nośnika informacji w przemyśle, oznaczałaby dla Xeroksa poważne kłopoty, o ile firma ta nie byłaby w stanie zmienić profilu produkcji na niezwiązany z papierem. By być zatem przygotowanym

${ }^{7}$ U szczytu rozkwitu Biblioteka Aleksandryjska prawdopodobnie posiadała kopię każdego znanego rękopisu. Por. A.K. Pace, The Ultimate Digital Library: where the New Information Players Meet, Chicago 2003, s. 28.

8 Por. H.S. Elmikaty, Science education: on the agenda of the library of Alexandria, „Museum International” 2005, t. 57, nr 1-2, s. 92.

9 Por. E. Mittler, Libraries and international infrastructure for open access services, „Information Services \& Use” 2003, t. 23, nr 2/3, s. 117.

${ }^{10}$ Por. Z. Dobrowolski, Internet $i$ biblioteka, Warszawa 1998, s. 139.

11 Por. J. Licklider, Libraries of the future, Cambridge 1965, s. 17-18. Polskie wydanie: J. Licklider, Biblioteki przyszłości, przeł. A. Składanek, E. Stolarska, Warszawa 1970. 
na taką ewentualność, zdecydowano o utworzeniu laboratorium badawczego, którego zadaniem miało być rozwijanie technologii elektronicznej obróbki informacji ${ }^{12}$.

W rozwijającym się sektorze technologii komputerowych rozpoczęto więc poszukiwania nowego potencjału. Nowo powstające urządzenia wyposażone w odpowiednie edytory tekstów można było już wykorzystać w nowatorski sposób.

Pierwszy projekt, który nawiązał do idei zgromadzenia i udostępnienia wszystkich książek (pełnego uniwersum informacyjnego) in situ, zakładający wykorzystanie zdobyczy technologii informacyjnych (cyfryzacja dokumentów), przypada jeszcze na lata $70 . \mathrm{XX}$ wieku, a więc zanim powstał Web. W 1971 roku bowiem zainicjowano Projekt Gutenberg. Michael Hart w 1971 roku, pracując na komputerze Xerox Sigma V, ogłosił, że największą wartością tworzoną przez komputery będzie przechowywanie, pobieranie i wyszukiwanie wszystkiego tego, co jest gromadzone w bibliotekach, tym samym zainicjował Projekt Gutenberg, który stał się pierwszą biblioteką cyfrową. Idea projektu polegała na tym, aby do końca XX wieku zdigitalizować 10 tysięcy najważniejszych książek i udostępnić je publicznie. Pomysłodawca, pracując na jednym z kilkunastu komputerów podłączonych do ówczesnej sieci komputerowej, doszedł do wniosku, że w przyszłości tego typu sieć będzie dostępna publicznie dla wszystkich, toteż warto tą drogą udostępnić zbiory książkowe. Teksty książek wprowadzano ręcznie w postaci zwykłego tekstu sformatowanego w kodzie ASCII - dzięki temu zapewniono łatwy dostęp do ich treści ${ }^{13}$. Projekt ten rozwijany jest nadal, choć pomysł cyfryzowania dokumentów realizuje się również na inne sposoby. Upraszczając, można przyjąć, że proces cyfryzowania dokumentów przyśpieszyła inicjatywa firmy Xerox. Projekt Gutenberg niewątpliwie był nowatorski, jednakże słabą stroną tego przedsięwzięcia był niewystarczający wówczas sprzęt, który miał podołać zadaniu przechowywania ogromnych baz danych. Prace nad bazami danych rozpoczęto pod koniec lat 60., wtedy zademonstrowano pierwszą taką bazę dostępną online za pomocą tworzonej właśnie szczątkowej sieci. Dopiero jednak w połowie lat 80. zaprezentowano pierwsze dyski CD-ROM, na których można było przechowywać różne dane, co

12 P. Gawrysiak, Cyfrowa rewolucja: rozwój cywilizacji informacyjnej, Warszawa 2008, s. $190-191$.

${ }^{13}$ Por. M. Hart, The history and philosophy of Project Gutenberg, „Project Gutenberg” 1992 [online], [dostęp: 30.12.2010], dostępny w internecie: http://www.gutenberg.org/ wiki/Gutenberg:About; Wikipedia. The Free Encyclopedia [online], [dostęp: 26.12.2010], dostępny w internecie: http://en.wikipedia.org/wiki/Project_Gutenberg. 
przyśpieszyło dalsze działania w kierunku tworzenia dużych repozytoriów informacji cyfrowej ${ }^{14}$.

\section{World Wide Web ${ }^{15}$}

Na przełomie lat 80. i 90. Tim Berners-Lee implementował już do sieci internetowej usługę World Wide Web. Świadomy faktu, iż na coraz większej liczbie różnych komputerów podłączonych do internetu gromadzona jest coraz większa ilość informacji, założył, iż projektując W3, spróbuje stworzyć taką technologię, która zapewni dostęp do wszystkich informacji znajdujących się na wszystkich komputerach podłączonych do internetu. Zamierzeniem jego było stworzenie jednej, wielkiej przestrzeni informacyjnej (single, global information space) ${ }^{16}$. Web został więc obmyślony jako przestrzeń, w której mogą funkcjonować rozmaite informacje, czy - jak to określił sam twórca - uniwersalne medium służące wymianie wszelkich informacji (universal medium for sharing information) ${ }^{17}$.

Warto wspomnieć, że zasadniczą rolę $\mathrm{w}$ upowszechnieniu usługi WWW odegrała bibliotekarka. Otóż Berners-Lee zaprezentował WWW Paulowi Kunzowi - pracownikowi Stanford Linear Accelerator (SLAC) z Palo Alto - który po powrocie do macierzystego ośrodka przedstawił Web bibliotekarce Louise Addis. Dostrzegając potencjał WWW, zaczęła ona implementować W3 na potrzeby tamtejszej biblioteki. Web wydawał się odpowiedni do zaprezentowania fizykom z całego świata katalogu zbiorów ośrodka naukowego SLAC online. Za namową Addis postawiono w SLAC pierwszy serwer Webowy poza Europą ${ }^{18}$.

Inicjatywa Harta dowiodła możliwości wykorzystania tworzonych i rozwijanych w tamtym okresie technologii informacyjnych przy budowie cyfrowych zasobów piśmiennictwa. Natomiast projekt Bernersa-Lee zapewnił odpowiedni (prosty w obsłudze) interfejs, ułatwiający dostęp

${ }^{14}$ Por. J.M. Borwein, E.M. Rocha, J.F. Rodrigues, Communicating Mathematics in the Digital Age, Wellesley 2008, s. 113.

${ }^{15}$ World Wide Web jest jedną z usług internetu i, jak się zdaje, jest usługą najpopularniejszą. Skróconą formą określenia World Wide Web jest WWW oraz W3, określeniem synonimicznym zaś Web. Ponadto można używać określeń system (hipertekstowy), środowisko (hipertekstowe, cyfrowe), przestrzeń (hipertekstowa) oraz usługa. W dalszej części artykułu określenia te będą stosowane zamiennie.

${ }^{16}$ Por. T. Berners-Lee, Weaving the Web: The Original Design and Ultimate Destiny of the World Wide Web, New York 2000, s. 4.

17 Ibidem, s. 84.

${ }^{18}$ Ibidem, s. 45-46. 
do tych zasobów. Wpłynęło to na fakt podejmowania kolejnych działań na rzecz digitalizacji (zwłaszcza wytworów kultury pisma i druku).

\section{Digitalizacja}

Wdrożenie na początku lat 90. XX wieku WWW przyśpieszyło tworzenie kolejnych projektów digitalizacyjnych oraz jednocześnie przyczyniło się do propagowania pojęcia „,biblioteka cyfrowa" ${ }^{19}$. Termin ten będzie rozumiany szeroko. Za Christiną L. Borgman można przyjać, że

biblioteki cyfrowe są zbiorem źródeł elektronicznych i połączonych możliwości technicznych tworzenia, wyszukiwania i używania informacji. [...] Biblioteki cyfrowe są tworzone - a ich zbiory gromadzone i klasyfikowane - przez i dla społeczności użytkowników, a ich możliwości funkcjonalne wspierają potrzeby informacyjne i cele tej społeczności. Są elementem społeczeństwa, w którym jednostka i grupa komunikują się i współpracują wykorzystując dane, źródła wiedzy i systemy. W tym sensie rozwijają się, podnoszą jakość i integrują różne instytucje informacyjne jako miejsca, w których źródła informacji są wybierane, gromadzone, klasyfikowane, chronione i udostępniane użytkownikom ${ }^{20}$.

Choć mówi się o wielu bibliotekach cyfrowych, to słusznie Marek Nahotko zauważa, że powinno się "traktować wszystkie zasoby jako jedna, światową «bibliotekę»" 21 . Stwierdzenie to jest o tyle istotne, że pozwala ujmować tworzone oddzielnie na całym świecie rozmaite projekty digitalizacyjne jako połączone zasoby światowej biblioteki.

Dla porządku wywodu należałoby w tym miejscu oddzielić działania bibliotek oraz organizacji non profit od działań prywatnych przedsiębiorców, np. wydawców. Celem działania tych pierwszych jest zapewnienie powszechnego dostępu do wytworów szeroko pojętej kultury piśmienniczej, przede wszystkim do rękopisów, inkunabułów i druków, do których

${ }^{19}$ Wśród pionierów bibliotek cyfrowych wymienia się Vannevara Busha, Douglasa Engelbarta, Teda Nelsona oraz Tima Bernersa-Lee. Ich pomysły, jak się podaje, zwiastowały erę bibliotek cyfrowych. Por. L.A. Tedd, J.A. Large, Digital libraries: Principles and practice in a global environment, München 2005, s. 4-5.

${ }^{20}$ R. Szymula, Biblioteki cyfrowe - zagadnienia ogólne i problemy terminologiczne, „EBIB" 1999, nr 8 [online], [dostęp: 27.07.2012], dostępny w internecie: http://www. oss.wroc.pl/biuletyn/ebib08/szymula.html.

21 Por. M. Nahotko, Cyfrowa najmłodsza siostra bibliotek, „Konspekt” 2004, nr 19 [online], [dostęp: 27.07.2012], dostępny w internecie: http://www.wsp.krakow.pl/ konspekt/19/index.html. 
bezpośrednio dotrzeć już nie sposób, i/lub też takich, które mogą w niedalekiej przyszłości ulec zniszczeniu. Marta Grabowska podała, że

wśród zbiorów poddawanych digitalizacji różni autorzy wymieniają różne kryteria ich selekcji. Są to najczęściej: zabytki piśmiennictwa, literatura naukowa, dokumenty o wysokich walorach kulturowych (np. kanon literatury pięknej), kartkowe katalogi bibliotek, zbiory wymagające konserwacji (gazety i czasopisma), zbiory częstego wykorzystania (skrypty, podręczniki), zbiory regionalne, itp.22.

Cel jest więc jasny: udostępnić cenne obiekty wytworzone w piśmie przez ludzkość, które posiada się we własnych zbiorach. Z drugiej strony od początku czynnościami digitalizacyjnymi zajmowali się również wydawcy, którzy, jak się zdaje, w pierwszej kolejności starali (i starają) się zabezpieczać przed stratami finansowymi ponoszonymi według nich $\mathrm{z}$ powodu umieszczania ich publikacji w sieci. Stąd zapewne dostęp do repozytoriów czy bibliotek tworzonych przez wydawnictwa często wymaga wnoszenia opłat. Upraszczając, można przyjąć, że celem działania wydawców jest przede wszystkim digitalizacja prac wydanych przez wydawnictwo, na dostępie do których można wypracować zyski finansowe.

Niezależnie od różnych motywacji warto przypomnieć, $w$ formie przykładu, niektóre z pierwszych projektów digitalizacyjnych. Najwcześniejsze projekty tworzenia bibliotek cyfrowych skierowane były na digitalizację artykułów z czasopism. Wśród nich można wymienić The Mercury Electronic Library Project realizowany na Uniwersytecie Carnegie Mellon w Pittsburghu w stanie Pensylwania. Projekt przebiegał w latach 1989-1992, a jego celem było stworzenie na potrzeby uniwersytetu biblioteki cyfrowej zawierającej artykuły z zakresu informatyki. Kolejnym projektem digitalizacyjnym był CORE - Chemistry Online Retrieval Experiment. W pracach nad nim wzięły udział takie instytucje, jak Bellcore (Bell Communication Research, dziś część Telcordia Technologies), Uniwersytet Cornella, OCLC (Online Computer Library Center), American Chemical Society oraz Chemical Abstract Service. W ciągu czterech lat (1991-1995) zdigitalizowano 400 tysięcy stron artykułów z czasopism z zakresu chemii, wydanych przez American Chemical Society. W tych samych latach wydawca Elsevier Science przez TULIP, czyli The University Licensing Project, udostępnił dziewięciu głównym uniwersytetom w USA zdigitalizowaną zawartość 43 wydawanych przez siebie czasopism. Projekty Mercury, CORE i TULIP miały dowieść możliwości

${ }^{22}$ M. Grabowska, Biblioteka cyfrowa w środowisku wirtualnym. Nowe wyzwanie dla katalogów bibliotek w erze dokumentów elektronicznych, w: Biblioteki cyfrowe: projekty, realizacje, technologie, red. J. Woźniak-Kasperek, J. Franke, Warszawa 2007, s. 21. 
tworzenia bibliotek cyfrowych dostępnych online oraz zademonstrować korzyści płynące z takiego rozwiązania ${ }^{23}$. W 1990 roku Biblioteka Kongresu rozpoczęła program American Memory Project, którego celem było upowszechnienie $\mathrm{w}$ postaci cyfrowej najbardziej unikatowych kolekcji zdjęć, map, rękopisów i innych zbiorów specjalnych znajdujących się w zbiorach biblioteki. W 1995 roku, kiedy upowszechnił się Web (globalnie rozproszona hipertekstowa sieć umożliwiająca wymianę informacji), projekt ten stał się częścią nowej akcji - National Digital Library Program. Wyjściowym celem programu było udostępnienie online $\mathrm{w}$ ciągu pięciu lat pięciu milionów jednostek ze zbiorów biblioteki, co udało się zrealizować w roku 2000²4. W 1994 roku Biblioteka Kongresu zainicjowała także program Digital Libraries Initiative - program badań nad bibliotekami cyfrowymi realizowany wraz z kilkoma uniwersytetami ${ }^{25}$. Program sponsorowany był przez National Science Foundation, Agencję DARPA oraz National Aeronautical and Space Administration. W pierwszej fazie programu sfinansowano sześć pięcioletnich projektów badawczych i rozpoczęto publiczną debatę nad bibliotekami cyfrowymi, w której skoncentrowano się $\mathrm{w}$ szczególności na zagadnieniu jakości i użyteczności przyszłych usług i zbiorów cyfrowych ${ }^{26}$. Sukcesy wskazanych przedsięwzięć zaowocowały tym, że w latach 90 . kolejne projekty digitalizacyjne wdrażano coraz szybciej. Celem projektów było dostarczenie zbioru (pełnego in spe) określonych dokumentów.

Warto dodać, iż w 1995 roku rozpoczęto na Uniwersytecie Kalifornijskim w Santa Barbara pracę nad tworzeniem Cyfrowej Biblioteki Alexandria (Alexandria Digital Library). Nazwą tej biblioteki nawiązano wprost do Biblioteki Aleksandryjskiej, uznawanej przez pomysłodawców projektu za centrum wiedzy i ośrodek nauki ${ }^{27}$. W tym okresie

${ }^{23}$ Por. L.A. Tedd, J.A. Large, op.cit., s. 5. Projekt CORE jako projekt biblioteki cyfrowej scharakteryzowali E. Richard, G. Lorrin, L. Michael, N. Lorraine, O. Jan, W. Stuart, Making a digital library: the chemistry online retrieval experiment, "Communication of the ACM" 1995, t. 38, nr 4, s. 54. Należy jednak pamiętać, że w tym wypadku nie ma się do czynienia z digitalizowaniem zbiorów bibliotecznych. Celem projektu CORE było zdigitalizowanie wybranej liczby artykułów wydanych przez konkretnego wydawcę.

${ }^{24}$ Por. J. Andrews, D. Law, Digital libraries: Policy, planning and practice, Englewood 2004, s. 214.

${ }^{25}$ Por. L.A. Tedd, J.A. Large, op.cit., s. 5.

${ }^{26}$ Por. Digital library initiatives [online], [dostęp: 27.01.2011], dostępny w internecie: http://memory.loc.gov/ammem/dli2/.

27 Por. What is ADL? [online], [dostęp: 6.05.2012], dostępny w internecie: http:// www.alexandria.ucsb.edu/adl/about_adl.html. 
zaczęły powstawać także liczne międzynarodowe projekty współpracy. Jednym z najważniejszych w tym zakresie był program UNESCO „Pamięć Świata", w ramach którego na format cyfrowy przeniesione zostały najcenniejsze dzieła dokumentujące rozwój cywilizacji. Pod koniec lat dziewięćdziesiątych XX w. w strukturach tego programu funkcjonowało już 11 różnorodnych projektów dygitalizacji zbiorów, a liczba uczestniczących w nim krajów sukcesywnie wzrastała $^{28}$.

Jerzy Franke zauważył, że wśród projektów digitalizacyjnych, tj. tworzenia cyfrowych zbiorów powszechnie dostępnych, daje się wyróżnić kilka nurtów. Jednym $z$ nich jest tworzenie narodowego repozytorium cyfrowego, które zawierałoby nie tylko pełny zbiór dokumentów zaliczanych do kanonu tekstów danego kręgu kulturowego, lecz w ogóle kompletny jeśli chodzi o zgromadzenie wszystkich dzieł autorów o określonej narodowości i piszących w danym języku. Przykładem takiego przedsięwzięcia jest Francuska Biblioteka Narodowa, której głównym elementem jest od 1999 roku Gallica Classique (http://gallica.bnf.fr/). Inny typ działań podejmują Biblioteka Kongresu i Biblioteka Brytyjska. Ich projekty zakładają stworzenie reprezentatywnego wyboru najwartościowszych obiektów kolekcji bibliotecznej. Kolejny nurt tworzą zbiory tematyczne, tworzone nie tylko przez pojedyncze instytucje, lecz niekiedy i w kooperacji z innymi placówkami. Celem ich działań jest zbudowanie pełnego zbioru na dany temat. Przykładem mogą być prace Charlesa Darwina kolekcja The Complet Work of Charles Darwin (http://darwin-online.org. uk/) tworzona przez Uniwersytet w Cambridge. Tego typu projekty cechują m.in.: intensywne rozwijanie zbioru (aż do osiągnięcia zamierzonego efektu, tj. zgromadzenia pełnego korpusu), precyzyjnie określone kryteria doboru i selekcji materiałów, funkcjonalny interfejs zapewniający bezproblemowe korzystanie ze zbioru, wyposażenie w dodatkowe narzędzia ułatwiające dostęp do zbioru i umożliwiające pełnotekstowe przeszukiwanie, przeznaczenie naukowe, dydaktyczne i edukacyjne ${ }^{29}$. Słuszne jest więc stwierdzenie, że

niedoścignionym, często nieuświadomionym celem użytkowników zasobów informacyjnych $\mathrm{w}$ różnych formach jest idea, która przyświecała już 300 lat p.n.e. budowniczym Biblioteki Aleksandryjskiej - zgromadzenia w jednym miejscu wszystkich publikacji świata. Szacuje się, że cel ten osiągnięto wówczas w 30-70\%.

${ }^{28}$ M. Kowalska, Dygitalizacja zbiorów bibliotek polskich, Warszawa 2007, s. 10.

${ }^{29}$ Por. J. Franke, Googletheca Universalis?, w: Biblioteki cyfrowe: projekty, realizacje, technologie, red. J. Woźniak-Kasperek, J. Franke, Warszawa 2007, s. 121-123. 
Po dwóch tysiącleciach, dzięki technologiom informacyjnym, realna stała się możliwość udostępnienia światowej spuścizny piśmienniczej. Przełomowe w tym zakresie są inicjatywy skanowania milionów książek (tymczasem głównie w języku angielskim). Wydaje się, iż zapoczątkowały one bardzo złożony (m.in. kwestie praw autorskich), ale technicznie możliwy do realizacji proces budowy uniwersalnej globalnej biblioteki dysponującej cyfrowymi kopiami wszystkich multimedialnych produktów ludzkości: tekstów, obrazów, muzyki, materiałów wideo. Chodzi tu, poza drukiem, o informacje wyemitowane przez stacje radiowe i telewizyjne oraz bogactwo zasobów WWW. Zamiarem jest udostępnienie za pośrednictwem WWW wyników prac piśmienniczych ludzkości od początku rejestrowanej historii we wszystkich językach świata ${ }^{30}$.

Przyczyny skłaniające biblioteki i wydawców do udostępniania za pomocą internetu dorobku piśmienniczego ludzkości są różne, uzyskiwany jednak efekt końcowy dla użytkownika zdaje się podobny. Każdy umieszczający w przestrzeni Webu zdigitalizowane obiekty kultury piśmiennej przyczynia się do budowania wizji WWW jako wielkiej biblioteki ${ }^{31}$. Zanim podejmie się próbę odpowiedzi na pytanie: czym jest lub

${ }^{30}$ W. Gogołek, Komunikacja sieciowa. Uwarunkowania, kategorie i paradoksy, Warszawa 2010, s. 133. Warto przypomnieć na marginesie, że jednym z pierwszych nowożytnych przykładów biblioteki naukowej była biblioteka działająca na Uniwersytecie w Getyndze (rok założenia 1734). Jej celem było gromadzenie (także kupowanie) wszystkich ważnych publikacji naukowych, wydawanych na całym świecie. Wraz z tą biblioteką ukonstytuował się więc nowy model biblioteki, tj. centrum pracy naukowej dające bezpłatny dostęp do zgromadzonych dzieł oraz przechowujące te publikacje dla przyszłych pokoleń. Por. E. Mittler, op.cit., s. 117.

31 W tym kontekście zwracają uwagę działania internautów, którzy - niekiedy wbrew obowiązującemu prawu - do zasobów WWW dodają zeskanowane przez siebie różne dzieła. Działania te określa się mianem digitalizacji oddolnej, obywatelskiej, partycypacyjnej. A. Tarkowski, J. Hofmokl, M. Wilkowski, Digitalizacja oddolna. Partycypacyjny wymiar procesu digitalizacji dziedzictwa [online], [dostęp: 1.08.2012], dostępny w internecie: http://www.nina.gov.pl/docs/kultura2.0/ digitalizacja-oddolna.-partycypacyjny-wymiar-procesu-digitalizacji-dziedzictwa. pdf. Digitalizacja oddolna oznacza „,zaangażowanie w proces digitalizacji dziedzictwa kulturowego osób i instytucji spoza kręgu podmiotów tradycyjnie zajmujących się digitalizacją: instytucji kultury takich jak biblioteki, archiwa i muzea, czy wyspecjalizowanych firm komercyjnych z nimi współpracujących". Por. ibidem. W procesie udostępniania dokumentów drogą digitalizacji oddolnej wykorzystuje się serwisy internetowe lub niezależną infrastrukturę publikowania i wymiany treści (np. dedykowane strony WWW, grupy dyskusyjne, sieci P2P, fora internetowe). „Warto zauważyć, że wyraźną część takich działań stanowi digitalizacja pomocy naukowych: skryptów, opracowań, notatek, artykułów czy książek naukowych. Realizowana jest doraźnie przez studentów i często przybiera formy studenckiego 
czym powinna być nowa (współczesna) biblioteka uniwersalna, konieczne jest przypomnienie dwóch projektów wyszukiwarek internetowych.

\section{Wyszukiwarki internetowe}

Można przyjąć, że założenia Bernersa-Lee przerosły jego marzenia. W krótkim czasie World Wide Web zaczął się nieprawdopodobnie rozrastać, stymulując rozwój sieci internetowej. Internet stawał się coraz popularniejszy, co sprzyjało upowszechnianiu Webu (wzrost liczby tworzonych stron WWW). Szybki ich przyrost zaowocował stworzeniem specjalnych mechanizmów wyszukiwawczych, tj. wyszukiwarek internetowych. W kontekście niniejszych rozważań szczególnie dwa projekty są istotne ${ }^{32}$.

Dzieło Davida Filo i Jerry'ego Yanga (w 1994 roku doktorantów na Uniwersytecie Stanforda) porównuje się do Biblioteki Aleksandryjskiej. Nie zgromadzili oni ogromnego zbioru dokumentów, lecz stworzyli pierwszy na tak dużą skalę katalog internetu (ściślej: stron WWW), tj. wyszukiwarkę Yahoo. Gwarancją powodzenia całego przedsięwzięcia, o czym warto wspomnieć, było to, że do prac nad klasyfikowaniem zasobów internetowych Yahoo zatrudniało również zawodowych bibliotekarzy ${ }^{33}$. Yahoo na długo stało się synonimem internetowego przewodnika.

Również na Uniwersytecie Stanforda, choć w innych nieco okolicznościach, powstał podobny projekt. Larry Page (od 1995 roku) i Sergey Brin (od 1996 roku) jako doktoranci pracowali przy projekcie biblioteki

współdziałania. Trudno dostępne materiały skanowane są i udostępniane nawet przez wykładowców. W tym wypadku trudno jednoznacznie określić, czy są to działania nielegalne - czy też podejmowane w ramach dozwolonego użytku edukacyjnego [...]. Przykład ten pokazuje, że problem nielegalnej oddolnej digitalizacji dotyczy często publikacji, które z różnych względów są nieosiągalne w inny sposób dla przeciętnego użytkownika Internetu: barierą nie musi być jedynie cena. Archiwalne wydania komiksów czy nieosiągalne w bibliotekach książki czytane są na ekranach komputerów - trudno nie zauważać tutaj pewnego pozytywnego efektu związanego z ograniczaniem efektów wykluczenia związanych np. z mieszkaniem na wsi czy brakiem środków na wydatki kulturalne". Ibidem. Reasumując, działania te również przyczyniają się znacznie do uzupełniania światowych zasobów World Wide Web.

32 Omówienie wyróżnionych wyszukiwarek będzie skrótowe, zwrócę bowiem w nim uwage jedynie na nawiązywanie do koncepcji Biblioteki Aleksandryjskiej, nie będę natomiast omawiał samej technologii wyszukiwarek.

33 Por. A.K. Pace, op.cit., s. 28-29. 
cyfrowej (Stanford Digital Library Project) ${ }^{34}$. Celem projektu było znalezienie sposobu na precyzyjne wyszukiwanie informacji rozproszonych $\mathrm{w}$ różnych bazach danych ${ }^{35}$. Wtedy też, jak podał Ben Bunnell (menedżer pracujący w Google), przyszli twórcy Google założyli, że można by wszystkie książki powiązać w określony sposób za pośrednictwem cytatów oraz odesłań bibliograficznych z innymi książkami. W rezultacie powstałaby baza przypominająca funkcjonujący dziś mechanizm PageRank, tyle że odnosząca się do książek. Wykonanie tego zadania należałoby jednak poprzedzić wcześniejszym zdigitalizowaniem wszystkich książek, co wówczas było niemożliwe. Ideę tę przenieśli więc na obszar World Wide Web i zastosowali przy tworzeniu bazy stron WWW. Tak narodziła się w 1997 roku wyszukiwarka Google ${ }^{36}$. Pomysł udostępnienia książek online i umożliwienia przeszukiwania ich w podobny sposób, jak przeszukuje się strony WWW, został odłożony na kilka lat. Dopiero po eksperymentalnym oszacowaniu czasu digitalizowania 300-stronicowej książki bez jej uszkodzenia (co zajęło około 40 minut) przyjęli, że jest technicznie możliwe zdigitalizowanie wszystkich książek wydanych na całym świe$\mathrm{cie}^{37}$. Tym samym pomysłodawcy Google przystąpili do realizacji swojego wyjściowego założenia ${ }^{38}$.

${ }^{34}$ Por. M. Bahareth, Isay: Kings of the Internet, Bloomington 2010, s. 1; Wikipedia. The free encyclopedia [online], [dostęp: 12.01.2011], dostępny w internecie: http://en.wikipedia.org/wiki/History_of_Google.

35 Por. D. Kulbaka, Historia Google, „Webinside.pl” 8.09.2008 [online], [dostęp: 12.01.2011], dostępny w internecie: http://webinside.pl/artykul-264-historia-google. html; Wikipedia. The free encyclopedia [online], [dostęp: 12.01.2011], dostępny w internecie: http://en.wikipedia.org/wiki/Stanford_Digital_Library_Project; J. Andrews, D. Law, op.cit., s. 8.

${ }^{36}$ Larry Page zaznaczył, że zanim wraz Sergeyem Brinem opracowali wyszukiwarkę Google, myśleli o tym, jak udostępnić online wszystkie zbiory gromadzone w bibliotekach oraz umożliwić ich przeszukiwanie. Por. G. Flagg, Scanning the horizon, w: The whole digital library handbook, red. D. Kresh, Chicago 2007, s. 206. Warto więc pamiętać, że twórcom znanej wyszukiwarki internetowej pierwotnie przyświecał cel udostępnienia całego światowego uniwersum książkowego.

37 Por. B. Bunnell, Google Book Search and Google Scholar [online], [dostęp: 12.01. 2011], dostępny w internecie: http://video.google.com/videoplay?docid=-87625147659 27564293\#.

${ }^{38}$ Alex Chitu na blogu dotyczącym informacji o Google przypomniał, że od samego początku intencją twórców Google było zdigitalizowanie wszystkich książek. Por. A. Chitu, Google's Digital Library of Alexandria [online], [dostęp: 6.05.2012], dostępny w internecie: http://googlesystem.blogspot.com/2006/08/googles-digital-library-ofalexandria.html. 


\section{Google Books}

Rozmach przedsięwzięcia firmy Google podkreślił Franke, porównując tę inicjatywę do dzieła Konrada Gesnera (Bibliotheca Universalis) w artykule Googletheca Universalis? ${ }^{39}$. Już w 2003 roku firma Google rozpoczęła projekt Google Print, który skierowany był do oficyn odpowiedzialnych za aktualną amerykańską produkcję wydawniczą. Choć wstępne prace digitalizacyjne rozpoczęto jeszcze w 2002 roku, to oficjalnie dopiero w 2004 roku zainaugurowano digitalizację światowych zbiorów bibliotecznych. Firma podpisała porozumienie z 15 bibliotekami naukowymi, zlokalizowanymi m.in. na takich uniwersytetach, jak Harvard, Oxford, Stanford ${ }^{40}$. Celem Google Books Library Project stało się zdigitalizowanie tej części zbiorów bibliotecznych i udostępnienie ich wersji cyfrowych w internecie - które nie podlegały już ochronie praw autorskich ${ }^{41}$. Dziś projekt funkcjonuje pod nazwą Google Books (wcześniej Google Print, Google Book Search) ${ }^{42}$. Google Books składa się z dwóch zasadniczych podprojektów: Google Books Library Project (wcześniej nazwany Google Print Library) oraz Google Books Partner Program (wcześniej znany pod nazwą Publisher Program). Ten ostatni polega na tym, że poszczególne oficyny udzielają zgody na umieszczenie zeskanowych wersji ich publikacji w bazie danych i udostępnienie ich internautom. Wydawnictwa zgodnie z zawieranymi umowami w każdej chwili mogą się wycofać z udziału w projekcie. Franke wyraził słuszne obawy co do możliwości objęcia przez Google Books Partner Program całej produkcji wydawniczej, choćby z powodu trudności w zrealizowaniu tego zamierzenia w zakresie produkcji wydawniczej krajów Trzeciego Świata. Jeśli chodzi o produkcję amerykańską i europejska, to możliwości osiągnięcia wyjściowego celu wypadają dużo pomyślniej. Od 2005 roku systematycznie zwiększa się liczba lokalnych wydawców z różnych krajów przyłączających się do programu. Innym problemem w przedsięwzięciu Google jest oszacowanie całej produkcji wydawniczej - tak naprawdę trudno ustalić, ile książek trzeba scyfryzować ${ }^{43}$. W połowie 2010 roku firma Google oszacowała, że na świecie jest 129864880 różnych książek (można się domyślić,

39 Por. J. Franke, op.cit.

${ }^{40}$ Dziś z projektem współpracuje 19 dużych bibliotek naukowych. Por. Biblioteki wspótpracujace [online], [dostęp: 7.10.2011], dostępny w internecie: http://books.google.com/googlebooks/partners.html.

${ }^{41}$ Por. J. Franke, op.cit., s. 124.

${ }^{42}$ Wikipedia. The free encyclopedia [online], [dostęp: 7.10.2011], dostępny w internecie: http://en.wikipedia.org/wiki/Google_Books.

${ }^{43}$ Por. J. Franke, op.cit., s. 124-138. 
że jest to liczba różnych wydań ${ }^{44}$. Niezależnie od pojawiających się przeszkód inicjatywa Google, wyrażająca się mnogością rozmaitych umów zawieranych z wydawcami i bibliotekami, ciężar kosztów prac, które pokrywa Google, jak również zapewnienie zaplecza technologicznego, które firma Google wykorzystuje do realizacji koncepcji udostępnienia zasobów wydawniczych in corpore ze strony projektu (in situ), wreszcie liczba już zeskanowanych i udostępnionych pozycji zaiste pozwalają określić tę ogromną i cały czas powiększającą się bazę danych nazwą googletheca ${ }^{45}$. Pod koniec 2009 roku firma Google informowała o ponad 10 milionach książek udostępnionych ze strony projektu ${ }^{46}$. Digitalizacja coraz większej liczby obiektów i udostępnianie ich via WWW zwiastuje powrót do koncepcji aleksandryjskiej - zgromadzenia całej ludzkiej wiedzy. Projekty cyfryzacji dokumentów rozwijane są ze wsparciem zarówno instytucji finansowanych z budżetu państw, jak również prywatnych inwestorów ${ }^{47}$. Jeden z dyrektorów zatrudnionych w Google stwierdził, że współczesna biblioteka aleksandryjska to po prostu internet, zwłaszcza z projektami takimi jak Google Books ${ }^{48}$.

Na arenie międzynarodowej, poza bibliotekami i wydawcami, pojawił się więc trzeci podmiot - prywatna firma, której jedno ze sztandarowych działań zostało skierowane na inkorporowanie całego uniwersum książek.

Choć w artykule próbuję wykazać analogie pomiędzy Webem i niektórymi jego technologiami a założeniami działania Biblioteki Aleksandryjskiej, a nie paralele pomiędzy Webem a kulturą książki w ogóle, co wymaga odrębnych analiz, to jednak warto przypomnieć o jednym fakcie. Tak jak kiedyś za sprawą wynalazku Gutenberga zrewolucjonizowano kulturę rękopiśmienna, tak dziś dzięki komputerom doświadcza się kolejnej rewolucji, tym razem cyfrowej ${ }^{49}$. Rewolucjonizuje się kulturę druku. Ciekawe może wydać się więc to, że „początkowo w nowym

${ }^{44}$ Por. You can count the number of books in the world on 25,972,976 hands [online], [dostęp: 9.10.2011], dostępny w internecie: http://googleblog.blogspot.com/2010/08/ you-can-count-number-of-books-in-world.html.

45 Takiego określenie używa Jerzy Franke (op.cit., s. 132).

46 Por. A tale of 10000000 books [online], [dostęp: 9.10.2011], dostępny w internecie: http://googleblog.blogspot.com/2009/10/tale-of-10000000-books.html.

47 Por. V. Vesna, Database aesthetics: of containers, chronofiles, time capsules, Xanadu, Alexandria and the World Brain [online], [dostęp: 5.05.2012], dostępny w internecie: http://time.arts.ucla.edu/AI_Society/vesna_essay.html.

${ }^{48}$ Por. M. Murrell, Digital + library: mass book digitization as collective inquiry, „N.Y.L. Sch. L. Rev." 2010/11, t. 55, s. 231.

49 Por. M. Góralska, Cyfryzajca kultury ksiażki - koncepcje i realizacje, „Bibliotheca Nostra" 2009, nr 3-4, s. 17; M. Góralska, Perspektywy e-booków w kontekście rozwoju 
środowisku komunikacyjnym częściej pojawiają się treści opublikowane już wcześniej w innej postaci niż takie, które upowszechniane są po raz pierwszy $^{\prime 50}$. Rozmach i liczba przedsięwzięć digitalizacyjnych jest tego najlepszym dowodem. Zauważalne jest, iż

technologia spowodowała, że gospodarka zbiorami oparta na budowie własnych zasobów przestała być najważniejsza [...]. Biblioteka przestała być tylko miejscem przechowywania piśmiennictwa, stała się również instytucją umożliwiającą dostęp do niego [...]. Biblioteka może być postrzegana i traktowana jako zbiór względnie oddzielnych zasobów ${ }^{51}$.

\section{Biblioteka uniwersalna - problemy}

Warto podjać próbę odpowiedzi na kilka zasadniczych pytań. W pierwszej kolejności: czym jest lub czym powinna być nowa (współczesna) biblioteka uniwersalna? Biblioteka uniwersalna to taka biblioteka, która składa się z uniwersalnej (mającej powszechne i wszechstronne zastosowanie) kolekcji zbiorów - wytworów szeroko pojętej kultury pisma (rękopisy, druki, obiekty tworzone w postaci cyfrowej). Novum natomiast miałby stanowić powszechny dostęp do tych zbiorów, który jest możliwy dzięki cyfrowym i sieciowym technologiom informacyjnym. Zbiory powinno się najpierw scyfryzować, a następnie ich digitalne kopie udostępnić przez sieć, lub też uzyskać cyfropisy, tj. dzieła born digital, a także przygotowane do publikacji drukiem wersje cyfrowe prac. Jakie więc prace powinny zasilać światową bibliotekę uniwersalną? Przede wszystkim zbiory bibliotek, muzeów i archiwów, publikacje poszczególnych oficyn wydawniczych (włączając dzieła aktualnie wydawane). Powinno uwzględniać się również prace umieszczane $\mathrm{w}$ różnych repozytoriach, być może także prace powstałe $\mathrm{w}$ ramach self-publishingu (samopublikowania $^{52}$ oraz rozmaite inedita. Dodatkowo zgromadzone dzieła powinny

komputerów jako urządzeń uniwersalnych i specjalistycznych, w: Biblioteka, ksiązka, informacja, Internet 2010, red. Z. Osiński, Lublin 2010, s. 77.

${ }^{50}$ M. Góralska, Rewolucja Gutenberga - przełom cyfrowy. Próba porównania, w: EBIB Materiaty konferencyjne $n r 17$ [online], [dostęp: 1.08.2012], dostępny w internecie: http://www.ebib.info/publikacje/matkonf/mat17/goralska.php.

${ }^{51}$ M. Górny, Od gromadzenia zbiorów do zarządzania zasobami, w: Stan i potrzeby polskich bibliotek uczelnianych. Materiały z ogólnopolskiej konferencji naukowej. Poznań, 13-15.11.2002, red. A. Jazdon, A. Chachlikowska, Poznań 2002, s. 107-108.

${ }^{52}$ Piotr Nowak używa polskojęzycznego odpowiednika terminu ,, self-publishing” "samopublikacja". P. Nowak, "Samopublikowanie": stara metoda - nowy sens w dobie e-science, „Biblioteka” 2009, nr 13, s. 91. 
zawierać prace we wszystkich językach świata i powinny być dostępne dla wszystkich.

Poza ustaleniem, co powinno zasilić zbiory biblioteki uniwersalnej, należy jeszcze odpowiedzieć na pytanie: jak skutecznie zapewnić dostęp do zgromadzonych zbiorów? Czy po prostu z przestrzeni World Wide Web, czy też może z określonego adresu URL?

Na pytanie, czy World Wide Web może być taką biblioteką uniwersalną komunikolog Jay David Bolter odpowiedział twierdząco ${ }^{53}$. Stale można powiększać zasoby Webu, każdy nowo dodany obiekt automatycznie staje się częścią całej kolekcji, za pomocą odpowiednich narzędzi wyszukiwawczych zbiory te są udostępniane użytkownikom końcowym. Słusznie zauważa więc Marek Nahotko, że

od początku istnienia Web, bibliotekarze mieli tendencję do traktowania go jako wielkiej biblioteki cyfrowej. Rzeczywiście, jeżeli dostępność do materiałów z innego końca kuli ziemskiej jest taka sama, jak do materiałów z własnej instytucji, to wówczas - z punktu widzenia użytkownika - wszystkie materiały dostępne poprzez komputer przyłączony do sieci mogą konceptualnie należeć do pojedynczej, jednolitej biblioteki cyfrowej ${ }^{54}$.

Jednakże z punktu widzenia użytkownika przeglądanie całego Webu $\mathrm{w}$ poszukiwaniu konkretnych prac jest kłopotliwe, dużo prostsze zdaje się docieranie do pertynentnych informacji z przestrzeni jednego adresu URL, serwisu czy technologii. Dlatego też o wiele częściej wskazuje się, iż uniwersalną biblioteką jest (może być) określone „miejsce” w Webie, a nie Web per se.

Uniwersalną biblioteką miał być realizowany w latach 2001-2007 The Million Book Project ${ }^{55}$. Projekt nadzorowany był przez Uniwersytet Carnegie Mellon, we współpracy z Indiami i Chinami. Zasoby udostępnione ze strony projektu (http://www.ulib.org/) oszacowane są na ponad 1,5 miliona książek. Większość z nich została napisana w językach chińskim, indyjskim, arabskim i francuskim ${ }^{56}$.

Do Biblioteki Aleksandryjskiej porównuje się powstałe w 2005 roku konsorcjum Open Content Alliance i wskazuje, że może ono stworzyć

${ }^{53}$ Por. J.D. Bolter, Writing space: computers, hypertext, and the remediation of print, Mahwah 2009, s. 94.

${ }^{54}$ M. Nahotko, Metadane: sposób na uporzadkowanie Internetu, Kraków 2004, s. 37.

55 Por. C.J. Bonk, The world is open: how Web technology is revolutionizing education, San Francisco 2009, s. 84.

${ }^{56}$ Por. R. Stross, Planet Google: one company's audacious plan to organize everything we know, New York 2008, s. 92-93. 
współczesną bibliotekę uniwersalną ${ }^{57}$. Celem działania konsorcjum jest udostępnienie po pierwsze książek, na których nie ciążą już ograniczenia prawne niepozwalające na ich swobodne rozpowszechnianie, oraz po drugie prac w porozumieniu z właścicielami praw, którzy wyrażają zgodę na umieszczenie ich jako powszechnie dostępnych ${ }^{58}$. Konsorcjum zrzesza wiele bibliotek (np. Bibliotekę Brytyjską), uniwersytetów (np. Uniwersytet Cornella) i organizacji (np. European Archive) z całego świata. Administrowaniem zajmuje się Archiwum Internetowe (Internet Archive), które zapewnia również przestrzeń magazynową dla digitalizowanych książek i udostępnia zeskanowane prace ${ }^{59}$.

Wśród projektów bibliotek uniwersalnych wymienia się też zainicjowany w 2007 roku projekt Open Library (http://openlibrary.org/). Tworzony jest on przez Archiwum Internetowe przy współpracy z licznymi bibliotekami. Twórcy swój zamiar wyartykułowali dewizą ,,jedna strona WWW dla wszystkich kiedykolwiek opublikowanych książek" ${ }^{\prime \prime 0}$. Na stronie WWW Open Library udostępnia się ponad milion książek ${ }^{61}$.

Inną inicjatywą jest tworzona od 2009 roku, pod auspicjami UNESCO i Biblioteki Kongresu oraz przy współpracy wielu bibliotek na świecie, World Digital Library (http://www.wdl.org/en/). Celem projektu jest bezpłatne udostępnienie przez internet znaczących dla rozwoju kultury materiałów pochodzących $\mathrm{z}$ całego świata. W zbiorach biblioteki znajduje się nieco ponad 6 tysięcy obiektów ${ }^{62}$.

Wśród barier uniemożliwiających zrealizowanie projektu biblioteki uniwersalnej wymienia się m.in.: fakt niszczenia książek (celowego, np. w wyniku wojen, i niecelowego, np. w wyniku kataklizmów naturalnych), restrykcyjne przepisy prawa utrudniające rozpowszechnianie dzieł (prawo typu copyright, cenzura), trudności w ustaleniu precyzyjnych kryteriów doboru materiałów do zasobów takiej biblioteki (np. czy współcześnie tworzone rękopisy powinny zasilać jej zbiory), niechęć wydawców do nieodpłatnego i powszechnego udostępniania prac $^{63}$.

${ }^{57}$ Por. J.B. Bengston, The birth of the universal library, "NetConnect” 2006, t. 131, s. 3.

58 Ibidem.

59 Open Content Alliance [online], [dostęp: 31.07.2012], dostępny w internecie: http://www.opencontentalliance.org/.

${ }^{60}$ Por. Open Library [online], [dostęp: 1.08.2012], dostępny w internecie: http:// openlibrary.org/about.

${ }^{61}$ Ibidem.

${ }^{62}$ Por. World Digital Library [online], [dostęp: 1.08.2012], dostępny w internecie: http://www.wdl.org/en/.

${ }^{63}$ Por. Wikipedia. The free encyclopedia [online], [dostęp: 31.07.2012], dostępny w internecie: http://en.wikipedia.org/wiki/Universal_library. 
Znacznym utrudnieniem jest ograniczony na mocy prawa dostęp do aktualnie krążących w obiegu prac, a namawianie wydawców do nieodpłatnego ich udostępnienia jest bardzo uciążliwe. Projekty takie jak omówiony wyżej Google Books (również określany mianem „biblioteka uniwersalna" ${ }^{64}$ ) pokazują jak problem ten ominąć. Nie obywa się to jednak bez naruszenia prawa. W działaniach Google na tym polu dostrzega się wiele nieprawidłowości. Na przykład książki znajdują się w sieci, zanim zaaprobują to właściciele praw autorskich ${ }^{65}$. Po udostępnieniu w sieci utworu Google przewiduje określony czas, w jakim uprawnione podmioty mogą zgłaszać sprzeciw wobec umieszczania tam ich dzieł. Brak sprzeciwu oznacza zgodę na elektroniczną publikację treści. Problemem jest także zakres i czas trwania ochrony prawnoautorskiej, który w różnych krajach jest różny, przez co trudno ustalić, czy dane dzieło w jakimś kraju nie podlega jeszcze ochronie ${ }^{66}$. To zapewne mocna pozycja potentata w branży IT pozwala firmie Google na podejmowanie ryzyka udostępniania dzieł z naciąganiem prawa. W odniesieniu do tego zjawiska, niekiedy, pojawiają się dodatkowe porównania - działania Google przypominają nieco działania Biblioteki Aleksandryjskiej, w podobny - "agresywny" (w myśl zasady "cel uświęca środki”) - sposób dąży się do uzyskania jak największej kolekcji zbiorów (w perspektywie - wszystkich) ${ }^{67}$. Robert Darnton dostrzega też inne poważne zagrożenie. Jego zdaniem korzystanie ze zgromadzonej w bibliotece Google kolekcji będzie w przyszłości odpłatne ${ }^{68}$. Odpłatność zdaje się przekreślać myśl o Google Books jako o bibliotece uniwersalnej, choć w opinii Darntona projekt ten staje się ekwiwalentem Biblioteki Aleksandryjskiej w XXI wieku ${ }^{69}$.

Otwarte pozostaje również inne pytanie: czy biblioteka uniwersalna powinna udostępniać wszystkie możliwe informacje utrwalone na wszelkich dostępnych nośnikach nośników informacji, następnie przekonwertowane do postaci numerycznej lub pierwotnie wytworzone $\mathrm{w}$ postaci

64 Por. A. Grafton, Worlds made by words: scholarship and community in the modern West, Cambridge 2009, s. 306; S. Vaidhyanathan, Googlization of everything (and why we should worry), Berkeley-Los Angeles 2011, s. 150.

${ }^{65}$ Debata o cyfrowej bibliotece publicznej, „Rzeczpospolita”, 27.03 .2011 [online], [dostęp: 31.07.2012], dostępny w internecie: http://www.rp.pl/artykul/633006.html.

${ }^{66}$ Por. A. Malczewska, Biblioteki legalnie cyfrowe, „IT w administracji” 2009, grudzień [online], [dostęp: 31.07.2012], dostępny w internecie: http://www.bukowski-partners.pl/images/File/5255-it-prawo.pdf, s. 52-53.

${ }^{67}$ Por. R. Goldsborough, Toward a universal library, „Teacher Librarian” 2008, t. 35, nr 3, s. 14.

${ }^{68}$ Por. R. Darnton, The case for books: past, present, and future, New York 2009, s. 11.

${ }^{69}$ Ibidem, s. 17. 
cyfrowej, czy też określone zasoby, np. zdigitalizowane wydawnictwa zwarte i ciagłe? Prawdopodobnie lepiej byłoby kryteria doboru materiałów uściślić i zawęzić do określonych kategorii. Tak tworzy się wskazane projekty, określane jako biblioteki uniwersalne. Z drugiej jednak strony, jeżeli Web ma pretendować do miana biblioteki uniwersalnej, to za jego pośrednictwem powinna być możliwość (przynajmniej potencjalnie) dotarcia do wszelkich obiektów informacyjnych. Teoretycznie jest to prawdopodobne, praktycznie raczej nie. Podstawowym problemem jest dostęp do tzw. głębokiego Webu, czyli zasobów nieindeksowanych przez algorytmy popularnych wyszukiwarek. Co prawda, tworzy się wyszukiwarki (nawet metawyszukiwarki) głębokiego Webu, ale i one nie zapewniają pełnego dostępu do zasobów. Już to ogranicza dotarcie do wszystkiego, co jest $\mathrm{w}$ internecie, ale przez Web jest trudno dostępne (np. pliki w sieciach P-2-P) lub w ogóle niedostępne (np. pliki umieszczone na podłączonych do internetu komputerach osobistych).

Nawet zawężenie doboru kolekcji biblioteki uniwersalnej do książkowych publikacji drukowanych nie rozwiąże problemu. Dziś, zdaniem literaturoznawcy i bibliotekarza Uwe Jochuma, idea aleksandryjska jest nieaktualna. Powstało bowiem tak wiele gałęzi wiedzy, co pociągnęło za sobą ogromny przyrost piśmiennictwa, iż nie sposób zgromadzić czy nawet udostępnić wszystkiego, co ludzkość wytworzyła w piśmie ${ }^{70}$.

Choć zdaje się, iż faktycznie niełatwo będzie wypełnić założenia idei aleksandryjskiej, to jednak nadal podejmowane są wysiłki na rzecz jej realizacji. Niezależnie od wskazywanych trudności stojących na przeszkodzie w „budowie” biblioteki uniwersalnej omówione zostaną jeszcze dwa projekty, które koncepcyjnie nawiązują do starożytnego przedsięwzięcia.

\section{Archiwum Internetowe}

W związku z łatwością tworzenia stron internetowych - a co za tym idzie, szybkim przyrostem ich liczby - a także równie łatwym usuwaniem stron z przestrzeni WWW oraz zastępowaniem ich nowymi pojawiło się niebezpieczeństwo bezpowrotnego utracenia informacji zawartych na stronach WWW. Strony internetowe można uznać za nietrwałe i ulotne źródła informacji. Powstała więc konieczność zaradzenia temu problemowi. Jedną z pierwszych prób podjęto, inicjując projekt Archiwum Internetowego (http://www.archive.org/index.php), a w szczególności jego

${ }^{70}$ Por. U. Jochum, The Alexandrian Library and its aftermath, "Library History" 1999, t. 15 , nr 1 , s. 5 . 
zasadniczej części, tj. Wayback Machine (http://www.archive.org/web/ web.php). Narzędzie to można określić jako swoistą "maszynę czasu”, która pozwala na cofnięcie się do określonych na osi czasu „miejsc” w sieci, aby sprawdzić, jak wtedy wyglądała określona strona WWW. Projekt rozpoczęto w 1996 roku, zaczęto wówczas magazynować i archiwizować światowe strony internetowe. Specjalne narzędzia nieustannie przeszukują światowy internet, automatycznie indeksują i kopiują do archiwum wybrane strony internetowe. Dodatkowo odnotowują również ważniejsze modyfikacje stron już dodanych ${ }^{71}$. W 2007 roku archiwum rejestrowało ponad 40 miliardów witryn, podczas gdy w 2011 roku było to już ponad 50 miliardów $^{72}$. Warto zauważyć, że projekt Archiwum Internetowego w zamierzeniu twórcy nawiązuje wprost do koncepcji Biblioteki Aleksandryjskiej ${ }^{73}$. W kontekście tworzenia projektu archiwum Brewster Kahle (współtwórca projektu) w jednym z wywiadów stwierdził nawet, że myśli o internecie jako o bibliotece i w związku z tym jego zadaniem jest budowanie biblioteki ${ }^{74}$. Dewizą oraz ideą przewodnią archiwum jest powszechny dostęp do całej ludzkiej wiedzy (towards universal access to all human knowledge $)^{75}$.

Co równie ciekawe, współczesna biblioteka aleksandryjska (Bibliotheca Alexandrina) posiada zabezpieczone kopie każdej strony WWW, które zostały zindeksowane (zachowane) przez Archiwum Internetowe ${ }^{76}$.

71 Wayback Machine oraz projekt Archiwum Internetowego został omówiony w artykule Grzegorza Gmiterka. Por. G. Gmiterek, Archiwa internetowe $i$ ich rola w tworzeniu globalnych zasobów informacyjnych (na przykładzie archiwum internetowego www.archive.org), w: Książka, biblioteka, informacja - między podziałami a wspólnota, red. J. Dzieniakowska, Kielce 2007, s. 555-556.

72 Por. ibidem, s. 556.

73 Por. M. Stępień, Syzyfowa praca. Uchronić przed zapomnieniem dziesięć miliardów stron WWW? Czemu nie!, "Internet” 2002, nr 10, s. 54-56.

${ }^{74}$ Por. M. Murrell, op.cit., s. 231.

${ }^{75}$ Por. The Bibliotheca Alexandrina: A truly digital library for the 21st century [online], [dostęp: 7.10.2011], dostępny w internecie: http://www.archive.org/about/bibalex_p_r. php.

76 Por. Bibliotheca Alexandrina - The New Library of Alexandria [online], [dostęp: 4.05.2012], dostępny w internecie: http://armchairtravelogue.blogspot.com/2010/03/ bibliotheca-alexandrina-new-library-of.html; Is there still a great Library of Alexandria, Egypt? [online], [dostęp: 4.05.2012], dostępny w internecie: http://quezi.com/776; A.F. Wood, M.J. Smith, Online communications: linking technology, identity and culture, Mahwash 2010, s. 29. Umieszczanie w Nowej Bibliotece Aleksandryjskiej skopiowanych przez Archiwum danych rozpoczęto w 2002 roku. Por. J. Masanès, Web archiving: with 6 tables, Berlin-Heidelberg-New York 2006, s. 208. 


\section{Alexa Internet}

W 1996 roku powstała Alexa Internet, firma, której jednym z zadań jest analiza ruchu w sieci i tworzenie np. zestawień najczęściej odwiedzanych stron internetowych. Nazwa firmy została utworzona w nawiązaniu do Biblioteki Aleksandryjskiej. Założyciele firmy dostrzegli bowiem paralelę pomiędzy największym repozytorium wiedzy starożytnego świata a internetem i jego potencjałem, który może zapewnić mu miano największego repozytorium wiedzy i informacji współczesnego świata ${ }^{77}$. Archiwum Internetowe indeksuje i tworzy kopie stron WWW, które śledzi i odnotowuje oprogramowanie Alexa ${ }^{78}$.

\section{Zakończenie}

WWW jest czymś podobnym do Biblioteki Aleksandryjskiej, miejscem, gdzie można prowadzić pracę naukową ${ }^{79}$. Istnieje bowiem (potencjalnie) możliwość uzyskania z tej przestrzeni wyników wszystkich współczesnych badań naukowych ${ }^{80}$. Dawniej wszelka wiedza konwertowana była do postaci stron zadrukowanych tekstem, dziś coraz częściej (w postaci pierwotnej oraz wtórnej) - do postaci digitalnej (digitalnego kodu binarnego) i jest udostępniania za pośrednictwem internetu i WWW. Jak podkreślają historycy i komunikolodzy, hipertekstowe środowisko Webu zapewnia dostęp do dużo większej ilości danych niż dawniej biblioteka w Aleksandrii ${ }^{81}$, stając się przez to czymś na kształt Biblioteki

77 Por. Wikipedia. The Free Encyclopedia [online], [dostęp: 19.04.2010], dostępny w internecie: http://en.wikipedia.org/wiki/Alexa_Internet; E.B. Quint, A gift of the web for the Library of Congres from Alexa Internet [online], [dostęp: 4.05.2012], dostępny w internecie: http://newsbreaks.infotoday.com/nbreader.asp?ArticleID=17893.

78 Por. B. Albert-László, Linked: the science of networks, Cambridge 2002, s. 176.

${ }^{79}$ Paweł Rybicki podał, że „dzieje bibliotek naukowych wykazują już w odległej przeszłości powiązania z ośrodkami prac badawczych. W starożytności Biblioteka Aleksandryjska była wspaniałym przykładem i wzorem takiego powiązania". P. Rybicki, Dawne i nowe formy pracy w bibliotekach naukowych, "Przegląd Biblioteczny” 1954, z. 1, s. 7.

${ }^{80}$ Por. M. Lahans, The bibliothece or Library of Alexandria [online], [dostęp: 4.05.2012], dostępny w internecie: http://www.mlahanas.de/Greeks/Library.htm. WWW nazywa się kolejnym po Bibliotece Aleksandryjskiej wielkim repozytorium różnych dokumentów. Por. B. Kahle, Preserving the internet, w: The future of the Web, New York 2007, s. 14; B.A. Shuman, Issues for libraries and information science in the Internet age, Englewood 2001, s. 179.

${ }^{81}$ Por. F. Stockwell, A history of information storage and retrieval, Jefferson 2001, s. 170. 
Aleksandryjskiej XXI wieku's2. Web umożliwił i ułatwił realizację idei, która przyświecała założycielom i twórcom Biblioteki Aleksandryjskiej, tj. kontrolowania rozproszonej po świecie wiedzy (utrwalonej w znakach graficznych na określonych nośnikach) ${ }^{83}$. WWW ułatwia zatem dostęp do całej niemalże wiedzy tak, jak kiedyś czyniła to Biblioteka Aleksandryjska ${ }^{84}$. Praktyka tej biblioteki wytyczyła na przyszłość pewne kierunki działań, tj. zgromadzenie i udostępnienie całej (określonej) ludzkiej wiedzy, np. wszystkich książek. Dzisiaj, m.in. za sprawą projektów digitalizacyjnych, pomysł ten nabiera nowego znaczenia, natomiast wiele projektów sieciowych (Yahoo, Google, biblioteki uniwersalne, Archiwum Internetowe, Alexa Internet) swym rozmachem wprost nawiązuje do projektu aleksandryjskiego.

\author{
SEBASTIAN D. KOTUŁA
}

\title{
From the Ancient Library of Alexandria to the World Wide Web
}

Aвstract. The article attempts to show parallels between WWW and the Ancient Library of Alexandria. In its conceptual approach, WWW is very much influenced by the methods, organizational procedures and information management procedures that have been worked out and developed within the book culture. There is a striking similarity between WWW and the principal task to be performed by libraries, which is to preserve and protect as much of the mankind's cultural heritage as possible, i.e., to collect the multitude of information data in substance and to make it available in one place in situ. Furthermore, the increment of information within the www space (i.e., the increase in the number of WWW pages) has ultimately led to a necessity of a creation of appropriate information technologies that would be capable of managing these digital objects. When some of these technologies were already in the making, some of their authors referred to the main idea that had motivated the creators

${ }^{82}$ Por. M. Hoechsmann, S.R. Poyntz, Media literacies: a critical introduction, Malden 2012, s. 4.

${ }^{83}$ Por. R. MacLeod, The Library of Alexandria: centre of learning in the ancient world, London 2004, s. 9.

${ }^{84}$ Por. S. Dietz, Telling stores: procedural authorship and extracting meaning from $m u$ seum databases [online], [dostęp: 4.05.2012], dostępny w internecie: http://www.museumsandtheweb.com/mw99/papers/dietz/dietz.html. 
of the Ancient Library of Alexandria, i.e., the idea of a creation of a full and extensive information repository. The present article discusses these technologies and indicates their conceptual similarities with the Alexandria Library.

Key words: Library of Alexandria, World Wide Web, book culture, repositiory of knowledge and information. 
